\title{
Business Communication Strategies: Analysis of Internal Communication Processes
}

\author{
Bayad Jamal Ali ${ }^{1}$, Govand Anwar ${ }^{2}$, Bayar Gardi ${ }^{3}$, Baban Jabbar Othman ${ }^{4}$, Hassan \\ Mahmood Aziz ${ }^{5}$, Shahla Ali Ahmed ${ }^{6}$, Pshdar Abdalla Hamza ${ }^{7}$, Nechirwan Burhan \\ Ismael $^{8}$, Sarhang Sorguli ${ }^{9}$, Bawan Yassin Sabir ${ }^{10}$
}

\author{
${ }^{1}$ Business Administration Department, Komar University of Science and Technology, Sulaimani 46001, Kurdistan Region - Iraq \\ 2,3,9,10 Department of Business Administration, College of Administration and Financial Sciences, Knowledge University,44001 Erbil, \\ Kurdistan Region, Iraq \\ ${ }^{4}$ Faculty Technology Management and Business, Universiti Tun Hussein Onn Malaysia 86400 Parit Raja, Johor, Malaysia. \\ ${ }^{5}$ Department of Accounting and Finance, Faculty of Economics and Administrative Sciences, Cyprus International University, Mersin 10, \\ Haspolat 99040, Cyprus. \\ ${ }^{6}$ Department of Guidance and Psychological Counseling, Atatürk Faculty of Education, Near East University, Turkey \\ ${ }^{7}$ Department of Business Administration, Kurdistan Technical Institute, Sulaymaniyah, Iraq. \\ ${ }^{8}$ Department of Accounting, Cihan University - Duhok, Kurdistan Region, Iraq.
}

Received: 15 Feb 2021; Received in revised form: 25 Apr 2021; Accepted: 15 May 2021

(C2021 The Author(s). Published by TheShillonga. This is an open access article under the CC BY license (https://creativecommons.org/licenses/by/4.0/)

\begin{abstract}
The purpose of this research is to investigate the current situation of internal communication in the maintenance department in the cement industry. In most organizations, employees and managers have struggled with the thought of attempting to solve weak and bad communication between the two parties which mostly cause issues to an organization, whether in performance or cost wise. This research was carried out at the maintenance department in Cement Company. A quantitative method was used to gather relevant information regarding a study of internal communication in maintenance department in cement industry. The research findings were supported that current management at Cement industry implementing team meetings effectively. The current management at Cement industry is creating and using online-printed communications tools, organizing regular events. The research findings were supported that current management at Cement industry using online tools for internal communication. In terms of notice board communication, the researcher was not able to find any link between company's' standard as a fact of internal communication method and respondent's perception as research findings. At this point the researcher was able to point out the gap between this study and the fact of internal communication at maintenance department in Cement industry. According to the findings the researcher was able to find out the gap between site visit communication between perception and the fact. Concerns of face-to-face communication method, also, was not found in the standard of internal communication at cement industry. Accordingly, the researcher was able to point out the gap between face-to-face communication method as a fact and respondents' perception according to the research findings. The current management at Cement industry is establishing a regular, transparent communication with all employees covering the entire organization. The research findings were supported that current management at Cement industry implementing network communication effectively.
\end{abstract}

Keywords-Business Communication, Internal Communication, External Communication.

\section{INTRODUCTION}

Communication is considered to be the base of an organization's operation. The process of communication will have a huge role in maintaining the organization (Abdullah \& Othman, 2019). Communication within an organization is such an essential aspect of human carrying out that it is almost impossible to imagine a workplace without it. It is through interaction and communication with managers and other employees that a workplace can be maintained. Being an effective communicator is known as a 
necessary asset in getting along with individuals and obtaining a successful occupation (Top \& Ali, 2021). In the business world, effective communication is seen as an important element of a successful organization. In order to have effective communication within an organization, both types of communication should be included; internal communication such as coordination between departments, among employees and between manager and employees, and external communication such us suppliers, shareholders, agencies and customers. In terms of poor communication, the cost will be very high because it will cause negative results that decrease organizational performance (Anwar \& Abdullah, 2021).

Working together will create some essential formal and informal relationships among employees. Individuals have different personalities, perception, opinions, natures, and thinking. They will not be able to understand each other until they communicate effectively (Gardi et al. 2020). Sharing information within an organization is considered the simplest and the most effective management for employee's participation. Useful information sharing within an organization such us new events, organizational goals, service and activities will help to expose elements of staff from others (Prabhu et al. 2020).

This research will investigate the current situation of internal communication in the maintenance department at Cement Company. Anwar \& Shukur, (2015), defined internal communication as a process of exchanging information between employees and managers within an organization. Sultan et al. (2020) found a significant correlation between effective communication and organizational performance. Internal communication activities often known with less task comparing with external communication. Therefore, most managers do not realize the importance of internal communication within an organization (Demir et al. 2020). The absence of internal communication will cause loss of loyalty and support among employees (Abdullah \& Othman,2015). Effective communication within an organization has many benefits such as providing high quality of service, increased productivity, increased creativity, enhanced employee participation (Ali, 2021), a decreased rate of employee turnover and increased employee job satisfaction (Gardi, 2021). Also as stated by Othman et al. (2019), effective internal communication is essential for attaining organizational objectives as it influences management strategy to retain employees. Also, Anwar \& Abd Zebari, (2015), stated that an effective internal processes management within an organization is considered a vital element in the competition. It is essential that managers should be able to inform all employees at all levels in an organization with the right direction regarding their tasks in order to perform efficient work (Khan \& Abdullah, 2019).

Enhancing organizational communication will have positive results, for instance, enhancing relations with primary stakeholders such as customers will result in increasing profit and grow the business. Effective communication between departments or among employees will result in increasing performance (Othman et al. 2019). Enhanced communication with managers might result in positive job satisfaction, decreasing deviance and increasing organizational citizenship behaviour. Communication within an organization particularly between employees and managers is essential (Anwar, 2017). Most employees expect that managers will be able to answer all questions, inform them with of any changes, solve conflicts and inform them of the organization's procedures, policies and regulations (Ali, 2020). Since positive communication will affect employees' morale and productivity (Anwar, 2016), manager's effective communication is considered a factor to motivate employees to perform better which leads to increased organizational performance. On the other hand, when managers have poor communication, this will lead to demotivated employees as a result and will cause negative issues and decreasing organizational performance rather than the cost it takes. Another important communication factor between managers and employees is transmitting and delivering proper information on time. Sometimes communicating via voicemails or emails might not be enough (Andavar et al. 2020), in this case face to face communication will be required in order to receive an accurate message from managers. Current business environment has become very competitive therefore keeping and skilled staff is the main distinguishing factor (Abdulla et al. 2017).

Globally, internal communication is considered very essential. Most organizations are measured based on their turnover rate, as a result the rate of turnover in any organization will influence the organizational performance (Anwar \& Balcioglu, 2016). In the case of low rate of employee turnover, this indicates that the organization is able to retain their skilled employees through an excellent working environment with strong communication and team building which improves the individual performance. Abdullah \& Abdul Rahman, (2015), found that in every organization employees are considered the most valuable asset because they are delivering the services or products (Hameed \& Anwar, 2018).

The main question will be how to enhance business communication? Firstly, managers should be able to understand the communication process and its impact on 
specific outcomes. Secondly, they should be able to recognize bad and good communication and its results in an organization (Damit et al. 2019). The most important factor is they should be able to distinguish which communication works better in a certain situation (Anwar \& Ghafoor, 2017). A good communication process depends on organization's background that required being successful in a long-term plan. Communication stands for the key to efficiency, along with qualified capabilities (Faraj et al. 2021). In most organizations almost all employees spend their time communicating with each other, regardless of their positions in the hierarchy levels (Prabhu et al. 2020). At the present time, the number of employees in offices and services has increased, and effective communication, collaboration and coordination are highly needed in order to enhance organizational performance (Anwar \& Climis, 2017). Collaboration is essential while working in a team, because team working is not efficient without effective communication and collaboration. This is the main reason for the importance of communication practices within an organization. Moreover, the role of managers has increased in an organization (Ali, 2016). The managers should be able to create coordination and communication in both internal and external information, also managers should be able to transfer and transmit information to their subordinates (Prabhu et al. 2019).

Previous scholars proved that communication considered an important factor in practicing internal communication within an organization. Internal communication defined by (Anwar \& Qadir, 2017) as dealing with staff with a massive value through the carrying out the programs to achieve organizational goals (Abdullah \& Rahman, 2015). The researchers explained above the communication and relation with Organization so what if we have a specific Organization like a maintenance department? What is the maintenance department and what is the importance of such a function in Cement Plants? "Maintenance department is where people are concerned with fixing and maintaining production equipment and this team should be available $24 / 7$ to make sure that all equipment is running efficiently and no major failures are identified (Abdullah, 2019). Maintenance personnel are recognized as being one of the key levers for plant performance. In principle, Maintenance personnel do their work according to safety principles; they should be motivated, skilled, experienced and costconscious (Ali, 2014). Maintenance is team work. Each individual is trained and upgraded to evaluate risks and needs, be efficient in their work, adapt easily to production technologies and new developments (Anwar \& Louis, 2017).

\section{Statement of the problem}

Having a better understanding of communication concepts and factors that drive maintenance function performance to become better, and provides stable performance to affect the overall performance of the organization positively, let's go deeper to understand the strategic role and importance of communication in the maintenance department. In most organizations, employees and managers have struggled with the thought of attempting to solve weak and bad communication between the two parties that mostly cause issues to an organization, whether in performance or cost wise. Either managers blame employees with bad communication or employees believe that managers do not effectively communicate with them. Regardless of the two parties' fault or bad communication, at the end they should come together to find out where the communication has broken down. Managing day to day work activities and executing a successful business strategy will require an effective communication between managers and employees and also among employees. Spending time on communication especially from managers will have positive results for the organization's outcomes and cost reduction. In many organizations, employees are complaining concerning the weak manager's communication, especially on essential information that should be delivered to employees via emails or in meetings. Effective communication will lead to clarifying the weak points and problems; hence managers will be able to find a proper solution and implement it.

\section{Research objectives}

As we have a better understanding regarding the importance of communication and maintenance in an organization and noticed to what extent maintenance performance is linked with the organization's efficiency and productivity, we have to understand in an organization, why performance of maintenance is so important, how communication is affecting the performance of this department, we also need to know the communication style internally between sections of this department and communication style externally with other departments in the operation organization.

Thus, in order to figure out to which extent communication has role and effect on Maintenance department? Or some other factors other departments enhance, or cross functional activities are affecting the performance of Maintenance. The followings are the main research objectives:

- Describe and explore internal communication and information

- Explore the relationship between internal communication and the attainment of an organization's vision and mission. 
- It enhances employees' efficiency by providing information related to their tasks.

- Enhance the coordination work activities and maintenance department in Cement Company Identify internal communication practices which other organizations might get benefits from.

- Clarify to approach situations and problems.

- Determining effective internal communication factors.

- Clarify understanding of organizational values and purpose

- Defining key direction for enhancing internal communication.

- Promote the regular exchange of information between employees and managers in the maintenance department in cement company

- It assists managers to achieve organizational objectives.

- Eliminate or avoid any potential conflict between team members

- Internal communication assist managers to practice management functions and skills

- It helps managers to be able to gather information from different sources and implement the company's plan effectively by communication.

\section{Research questions}

The followings are the main research questions:

1. How can the maintenance department enhance business communication?

2. How does effective communication enhance organizational performance?

3. What are the main communication styles that influence employees to perform better?

4. What are the main communication styles that influence managers to perform better?

5. What are the internal communications' main factors?

\section{LITERATURE REVIEW}

Communication is defined as exchange of ideas, information and knowledge between two or more individuals to arrive at a mutual understanding (Ali \& Anwar, 2021). Communication is defined as information exchange by symbols, signals or words. It is the interchange of viewpoints, thought, belief and facts regarding the common purpose, efforts and interests (Khan \& Abdullah,
2019). Communication is defined as any behaviour that consequences in an exchange of meaning (Anwar \& Abdullah, 2021). Communication is the practice to transmit information between employees and organizations so based on the meaning of the message the responder can reply (Prabhu et al. 2020). Communication is the action of passing particular information from one individual to another (Ganeshkumar et al. 2019).

The communication is defined by many authors as the exchange of information between recipient and sender by which a message is directed from a point to another point and the communicators are associated all together through communication channels (Abdullah \& Afshar, 2019).Internal communication is defined by Abdullah \& Rahman, (2015) as necessary management activities in all organizations as it is considered as a vital factor for all employees at all levels in organizations to obtain information regarding their tasks and duties (Ali et al. 2021).Internal communication defined by Abdullah, (2018) as an outline of meanings and the individual interaction that take place within organizations (Saleh et al. 2021).

Othman \& Abdullah, (2016) defined internal communication as a process in which individuals share information with each other in order to achieve a mutual understanding. While Further, Abdullah \& Othman, (2016) defined internal communication as a social interaction through messages (Abdullah \& Othman, 2021). Abdullah \& Abdul Rahman, (2015) provides in his study four fundamental functions that internal communication could accomplish within an organization: informative function, control function, social function and expressive function. Additionally, internal communication presents a basic incentive in organizations that strengthens and enables employees to carry out their tasks effectively (Anwar \& Abdullah, 2021).

The importance of internal communication, the exchange of information and the transmission of meaning, is also discussed by Anwar \& Shukur, 2015) who refers to internal communication as the soul of an organization. The importance of communication can be explained by the fact that it is the tool that can both reveal and eliminate problems (Anwar \& Abd Zebari, 2015). Numerous models of communication described the nature of communication and the way it works within an organization. Many researchers supported the model SMCR (Anwar \& Surarchith, 2015). This model was found by Shannon and Weaver in 1949 (Anwar, 2017).

The SMCR model illustrates the process of the communication, which starts with a sender, a person who transfers a particular message. This action is called encoding when a sender is deciding on the content of the 
message and when to transmit that message (Anwar, 2016). In a safe working environment, the receiver will be able to receive the message from the sender without any issues. The message is then decoded, that is, the recipient understands the message by attaching meaning to it. When recipients get the message, they reply to the message in both or either verbal or nonverbal (Abdulla et al. 2017).

Choosing the right communication channels is considered as a difficult task within an organization. Though channels of communications are regularly assessed according to the expectations of the sender in terms of communication channels, it is essential to recognize that each communication channel depends on the situation and information required to be sent. Consequently, it is essential to select the right communication channel that fits best. This is very essential because employees within an organization are able to interpret and understand the message according to the situation, and the selected communication channels might make a real difference in receiving the message (Anwar \& Balcioglu, 2016).

In order to facilitate internal communication within an organization there are many communication channels that can be used. Hameed \& Anwar, (2018) provided several methods of internal communication. For instance, written communication, electronic communication (email and blogs), newsletters and magazines and so on (Anwar \& Ghafoor, 2017).

Furthermore, information such as events and news could be announced on notice boards as well as other types of social activities. At the present time, there are other sorts of internal communication channels that can be used within an organization such us phone conferences and video conferences (Anwar \& Climis, 2017).

Electronic internal communication is another channel that can be used within an organization, which enables employees to get information faster and easier. Additionally, it provides individuals with an access to important information required to accomplish their daily activities (Anwar \& Qadir, 2017).

Managers can give job or task instructions through topdown communication within an organization. A good example of top-down communication is an organizational chart; it shows everyone's tasks and responsibilities clearly. Although top-down communication is very important it will not be very effective communication just by itself. Managers should be able to get feedback from employees to make sure that the message was clear and understandable by their employees. In order for employees to be involved and part of the organization therefore, we can see the importance of the upward communication channel (Anwar \& Louis, 2017). Lastly, interpersonal, networking and social communications are very essential for each employee. Therefore, employees should communicate effectively with their co-workers and sharing information will create a horizontal communication within an organization (Anwar \& Abdullah, 2021).

The communication in all organizations compromises formal and informal communication along with three types of communication mentioned previously (Anwar \& Abdullah, 2021).

Many previous researchers declared that barriers in effective communication comprise several factors, for instance, international barriers, lack of interpersonal factors, badly designed messages, lack of planning and information overload (Prabhu et al. 2019). Insufficient internal communication creates the spreading of rumors, insecurity, irritation and disintegration. Many issues occur within an organization because of imperfect and inadequate communication (Anwar \& Qadir, 2017).

Many academic researchers declared that communication is the primary management activity within an organization, in view of the fact that it is essential that all employees at all levels within the organization receive information to do their tasks and duties on time and in a proper way, in order to achieve organizational goals or objectives. Furthermore, the significance of internal communication is not considered essential only in relation to the employee's tasks and duties (Abdullah \& Rahman, 2015). In a working day, employees are looking for social interactions with other coworkers and would like to be treated as an individual not only as an employee or co-worker. Although it is proved that internal communication is essential, many researches showed that there is a gap between perception and awareness of the significance of communication and actual attention to execute it into an action (Abdullah, 2019).

A good example is executing of an organizational strategy, and internal communication has a significant role in implementing it. In many organizations, most of the managers concentrate on strategy formulation rather than being focused on strategy implementation. Therefore, many organizational strategies have failed to be implemented due to poor internal communication. This shows the importance of internal communication within an organization and its impact on performance. So, it is clear that a manager should have excellent communication skills to execute organizational strategy. As we can see, managers might fail to execute strategy effectively because of lacking essential communication skills (Anwar \& Louis, 2017).

Every employee would like to know and understand the organization's direction and where the organization is heading, what the organizational objective is and how they will be able to achieve that specific objective. Therefore, it 
is very important that managers should communicate effectively with employees and clear out all uncertainty with organizational objectives. Obviously this can be done by internal communication between managers and employees. Additionally, research by Watson Wyatt (Ali \& Anwar, 2021) shows that companies with highly effective internal communication have higher levels of job satisfaction, higher market share, higher employee commitment and higher shareholder return. According to these two examples, the researcher can conclude that effective internal communication will be beneficial in creating a long-term relationship between management and employees and thus obtaining better future revenue for the organization (Khan \& Abdullah, 2019).

\section{METHODOLOGY}

This research is carried out at the maintenance department in Cement Company in Kurdistan region of Iraq. A quantitative method is used to gather relevant information regarding the internal communication in maintenance department. Methods comprised the procedures used for generating, collecting and evaluating data. The researcher gathered data for the study through distributing questionnaires as primary data. The questionnaire is prepared and distributed to the employees at the maintenance department in Cement Company. Secondary data is needed for conducting research work which is done by collecting it from recent academic articles, books and previous studies related to effect of internal communication on organizational performance.

A random sampling method was adopted to collect data, where all the maintenance department's employees will have equal chances of being selected from the sample group. The maintenance department in Cement Company currently has 97 employees, the population of this study will be 97 units and the target population of this study will be 78 units (as shown in the formula). The following formula presents the sample size calculation:

Sample size $=\frac{\mathbf{z}^{2} \times \mathbf{P} \times(\mathbf{1}-\mathbf{P})}{\mathbf{c}^{\mathbf{2}}}$

$\mathrm{Z}=\mathrm{Z}$ value (1.96 for $95 \%$ confidence level)

$\mathrm{p}=$ percentage picking a choice

$\mathrm{c}=$ confidence interval

Sample size $=\frac{(\mathbf{1 . 9 6})^{2} \times 0.5 \times(1-0.5)}{(0.05)^{2}}$

Sample size $=\frac{0.9604}{\mathbf{0 . 0 0 2 5}}$

Sample size $=384.16 \quad 3.950$

New sample size $=\frac{\text { Samplesize }}{1+\left\{\frac{\text { samplesize }-1}{\text { population }}\right\}}$
New sample size $=\frac{384.16}{1+\left\{\frac{384.16-1}{\mathbf{9 7}}\right\}}$

New sample size $=\mathbf{7 8}$ Units

\section{DATA ANALYSIS}

The purpose of this study is investigating the internal communication in the maintenance department in Cement Company. As mentioned previously a total of 78 respondents were involved in completing the survey. These respondents had different positions; some respondents were managers and others were engineers. The current study deals with internal communication criteria and seven factors were identified: team meetings, email communication, face to face communication, and site visits communication, network communication, notice board and text messaging. The respondents were asked to rate how important they perceived each item on five point ordered scales. The scales for organizational performance as a dependent factor were measured and evaluated on a five-point scale with potential answers ranging from strongly disagree to strongly agree. The scales for all independent factors: team meetings, email communication, face to face communication, site visits communication, network communication, notice board and text messaging were measured as well on a five point ordered scale which gave possible answers ranging from strongly disagree to strongly agree.

All data have been analyzed by using SPSS version 18. First section of data analysis is demographic data analysis consisting of respondent's age, gender, level of education, years of experience and marital status. Second section of data analysis consists of seven factors mentioned previously. For each of those factors, the researcher started analyzing each factor in four steps; first step was factor analysis to determine essential variables that clarify the outline of associations within a set of perceived variables.

\section{Demographic analysis}

This section presents respondents' background information involved in this study such as Age, level of education, years of experiences and marital status as shown below: Table (1), explains the percentage and frequency of the age of participants in this research; according to SPSS frequency analysis $7(9.0 \%)$ respondents from total of 78 were $20-30$ years old, $49(62.8 \%)$ of respondents from total of 78 were $31-40$ years old and $22(28.2 \%)$ of respondents from total of 78 were 41-50 years old. The majority of respondents were 31-49 years old, this means that most of the participants of this survey were mature, as a result, the researcher can rely on the research results. As for participants' marital status, it was found that 75 respondents $(96.2 \%)$ from total of 78 respondents were married and $3(3.8 \%)$ of respondents from total of 78 respondents were single. As for participants' 
level of education, it was found that $1(1.3 \%)$ of respondents from total of 78 respondents had a high school degree, 73 $(93.6 \%)$ of respondents from total of 78 respondents had a Bachelor's degree, 3 (3.8\%) of respondents from total of 78 respondents had M.A or M.Sc. and one of the respondents had other degree than listed in the questionnaire. The majority of respondents had B.A degrees; this means that most of the participants had a proper degree and the researcher can rely on the results of this survey as an academic analysis. As for participants' years of experience,
$2(2.6 \%)$ of respondents from total of 78 respondents had less than 1 year of experience, 2 (2.6\%) of respondents from total of 78 respondents had 1-3 years of experiences, 55 $(70.5 \%)$ of respondents from total of 78 respondents had 4 8 years of experiences, $10(12.8 \%)$ of respondents from total of 78 respondents had 9-13 years of experiences, and 9 $(11.5 \%)$ of respondents from total of 78 respondents had 1418 years of experiences. The greatest part of respondents had 4-8 years of experience, this range is considered reliable and the researcher can depend on the questionnaire results.

Table 1-Demographic analysis

\begin{tabular}{|c|c|c|c|c|}
\hline No & Items & Scales & Frequency & Percent \\
\hline \multirow[t]{3}{*}{1} & \multirow[t]{3}{*}{ Age } & $2-30$ & 7 & 9.0 \\
\hline & & $31-40$ & 49 & 62.8 \\
\hline & & $41-50$ & 22 & 28.2 \\
\hline \multirow[t]{2}{*}{2} & \multirow[t]{2}{*}{ Marital Status } & Married & 75 & 96.2 \\
\hline & & Single & 3 & 3.8 \\
\hline \multirow[t]{4}{*}{3} & \multirow[t]{4}{*}{ Level of education } & High school & 1 & 1.3 \\
\hline & & B.A & 73 & 93.6 \\
\hline & & M.A or M.Sc. & 3 & 3.8 \\
\hline & & Other & 1 & 1.3 \\
\hline \multirow[t]{5}{*}{4} & \multirow[t]{5}{*}{ Years of experience } & less than one year & 2 & 2.6 \\
\hline & & $1-3$ & 2 & 2.6 \\
\hline & & $4-8$ & 55 & 70.5 \\
\hline & & $9-13$ & 10 & 12.8 \\
\hline & & $14-18$ & 9 & 11.5 \\
\hline
\end{tabular}

Data analysis consists of seven sections. Each section consisted of four separate analyses; first step is factor analysis to determine essential variables that clarify the outline of associations within a set of perceived variables. Second step is Reliability statistics, the Cronbach's alpha reliability coefficient. Third step is correlation analysis to present the values of the identified correlation tests; it determines the strength of relationship between variables. And final step was regression analysis to find out whether the hypothesis was supported or not.

\section{Team meetings}

As for team meetings factor, it was found that the majority of respondents (mean $=3.5$ ) believed that team meetings are considered time consuming as seen in table (7) and figure (13). According to descriptive analysis, 2 respondents rated as strongly disagree, 12 respondents rated as disagree, 22 respondents rated as neutral, 29 respondents rated as agree and 13 respondents rated as strongly agree. The majority of respondents (mean=3.2) believed that team meetings are very essential for enhancing organizational performance as seen in table (8) and figure (14). According to descriptive analysis, 7 respondents rated as strongly disagree, 15 respondents rated as disagree, 21 respondents rated as neutral, 24 respondents rated as agree and 11 respondents rated as strongly agree. The majority of respondents (mean $=3.7$ ) believed that team meetings provide opportunities for employees to discuss and provide feedback and give their opinions as seen in table (9) and figure (15). According to descriptive analysis, one respondent rated as strongly disagree, 7 respondents rated as disagree, 22 respondents rated as neutral, 35 respondents rated as agree and 13 respondents rated as strongly agree. The majority of respondents $($ mean $=3.4)$ believed that the manager in the maintenance department of Cement industry has enough communication skills as seen in table (10) and figure (16). According to descriptive analysis, 5 respondents rated as strongly disagree, 8 respondents rated as disagree, 22 respondents rated as neutral, 33 respondents 
rated as agree and 10 respondents rated as strongly agree. The majority of respondents (mean=2.9) believed that the manager in the maintenance department of Cement industry does team meetings everyday as seen in table (11) and figure (17). According to descriptive analysis, 10 respondents rated as strongly disagree, 17 respondents rated as disagree, 24 respondents rated as neutral, 23 respondents rated as agree and 4 respondents rated as strongly agree. The majority of respondents (mean=3.4) believed that the manager in the maintenance department of Cement industry involves all employees in team meetings as seen in table (12) and figure (18). According to descriptive analysis, 3 respondents rated as strongly disagree, 10 respondents rated as disagree, 30 respondents rated as neutral, 25 respondents rated as agree and 10 respondents rated as strongly agree. The majority of respondents (mean=3.4) believed that the manager in the maintenance department of Cement industry effectively communicates with the team as seen in table (13) and figure (19). According to descriptive analysis, 3 respondents rated as strongly disagree, 8 respondents rated as disagree, 28 respondents rated as neutral, 29 respondents rated as agree and 10 respondents rated as strongly agree. The majority of respondents $($ mean $=2.9)$ believed that the manager in the maintenance department of Cement industry gives employees an opportunity to participate in decision making as seen in table (14) and figure (20). According to descriptive analysis, 11 respondents rated as strongly disagree, 14 respondents rated as disagree, 28 respondents rated as neutral, 20 respondents rated as agree and 5 respondents rated as strongly agree. The majority of respondents $($ mean $=3.5)$ believed that employees as a team in the maintenance department of Cement industry are providing ideas to enhance performance as seen in table (15) and figure (21). According to descriptive analysis, 10 respondents rated as strongly disagree, 30 respondents rated as disagree, 28 respondents rated as neutral, 10 respondents rated as agree and 5 respondents rated as strongly agree. The majority of respondents $($ mean $=3.5)$ believed that employees as a team in the maintenance department of Cement industry are committed to team meetings as seen in table (16) and figure (22). According to descriptive analysis, 4 respondents rated as strongly disagree, 5 respondents rated as disagree, 28 respondents rated as neutral, 32 respondents rated as agree and 9 respondents rated as strongly agree. The majority of respondents (mean=3.2) believed that the manager in the maintenance department of Cement industry is committed to team meetings as seen in table (17) and figure (23). According to descriptive analysis, 6 respondents rated as strongly disagree, 12 respondents rated as disagree, 28 respondents rated as neutral, 23 respondents rated as agree and 9 respondents rated as strongly agree.

Table 2-Team Meetings-Descriptive analysis

\begin{tabular}{|c|c|c|c|c|c|}
\hline No & Questions & Scales & Frequency & Percent & Mean \\
\hline \multirow{5}{*}{1} & \multirow{5}{*}{$\begin{array}{l}\text { Team meetings considered } \\
\text { time consuming }\end{array}$} & Strongly disagree & 2 & 2.6 & \multirow{5}{*}{3.5} \\
\hline & & Disagree & 12 & 15.4 & \\
\hline & & Neutral & 22 & 28.2 & \\
\hline & & Agree & 29 & 37.2 & \\
\hline & & Strongly agree & 13 & 16.7 & \\
\hline \multirow{5}{*}{2} & \multirow{5}{*}{$\begin{array}{l}\text { Team meetings are very } \\
\text { essential for enhancing } \\
\text { organizational } \\
\text { performance }\end{array}$} & Strongly disagree & 7 & 9.0 & \multirow{5}{*}{3.2} \\
\hline & & Disagree & 15 & 19.2 & \\
\hline & & Neutral & 21 & 26.9 & \\
\hline & & Agree & 24 & 30.8 & \\
\hline & & Strongly agree & 11 & 14.1 & \\
\hline \multirow{5}{*}{3} & \multirow{5}{*}{$\begin{array}{l}\text { Team meetings provide } \\
\text { opportunities for employee } \\
\text { to discuss and provide } \\
\text { feedback and give their } \\
\text { opinions }\end{array}$} & Strongly disagree & 1 & 1.3 & \multirow{5}{*}{3.7} \\
\hline & & Disagree & 7 & 9.0 & \\
\hline & & Neutral & 22 & 28.2 & \\
\hline & & Agree & 35 & 44.9 & \\
\hline & & Strongly agree & 13 & 16.7 & \\
\hline \multirow{2}{*}{4} & \multirow{2}{*}{$\begin{array}{l}\text { My manager has enough } \\
\text { communication skills }\end{array}$} & Strongly disagree & 5 & 6.4 & \multirow{2}{*}{3.4} \\
\hline & & Disagree & 8 & 10.3 & \\
\hline
\end{tabular}




\begin{tabular}{|c|c|c|c|c|c|}
\hline & & Neutral & 22 & 28.2 & \\
\hline & & Agree & 33 & 42.3 & \\
\hline & & Strongly agree & 10 & 12.8 & \\
\hline & & Strongly disagree & 10 & 12.8 & \\
\hline & & Disagree & 17 & 21.8 & \\
\hline 5 & My manager does team & Neutral & 24 & 30.8 & 2.9 \\
\hline & & Agree & 23 & 29.5 & \\
\hline & & Strongly agree & 4 & 5.1 & \\
\hline & & Strongly disagree & 3 & 3.8 & \\
\hline & My manaoer involves all & Disagree & 10 & 12.8 & \\
\hline 6 & employees in team & Neutral & 30 & 38.5 & 3.4 \\
\hline & meetings & Agree & 25 & 32.1 & \\
\hline & & Strongly agree & 10 & 12.8 & \\
\hline & & Strongly disagree & 3 & 3.8 & \\
\hline & My manager effectively & Disagree & 8 & 10.3 & \\
\hline 7 & communicates with the & Neutral & 28 & 35.9 & 3.4 \\
\hline & team & Agree & 29 & 37.2 & \\
\hline & & Strongly agree & 10 & 12.8 & \\
\hline & & Strongly disagree & 11 & 14.1 & \\
\hline & My manager gives us an & Disagree & 14 & 17.9 & \\
\hline 8 & opportunity to participate & Neutral & 28 & 35.9 & 2.9 \\
\hline & in decision making & Agree & 20 & 25.6 & \\
\hline & & Strongly agree & 5 & 6.4 & \\
\hline & & Strongly disagree & 10 & 12.8 & \\
\hline & My team is providing ideas & Disagree & 30 & 38.5 & \\
\hline 9 & to enhance department's & Neutral & 28 & 35.9 & 3.5 \\
\hline & performance & Agree & 10 & 12.8 & \\
\hline & & Strongly agree & 10 & 12.8 & \\
\hline & & Strongly disagree & 4 & 5.1 & \\
\hline & & Disagree & 5 & 6.4 & \\
\hline 10 & My team is committed to & Neutral & 28 & 35.9 & 3.5 \\
\hline & & Agree & 32 & 41.0 & \\
\hline & & Strongly agree & 9 & 11.5 & \\
\hline & & Strongly disagree & 6 & 7.7 & \\
\hline 11 & My manager is committed & Disagree & 12 & 15.4 & 20 \\
\hline 11 & to team meetings & Neutral & 28 & 35.9 & \\
\hline & & Agree & 23 & 29.5 & \\
\hline
\end{tabular}




\section{Email communication}

As for email communication factor, it was found that the majority of respondents $($ mean=3.4) believed that email communication is considered a fast tool to reach employees in the maintenance department of Cement industry. According to descriptive analysis, 4 respondents rated as strongly disagree, 9 respondents rated as disagree, 27 respondents rated as neutral, 28 respondents rated as agree and 10 respondents rated as strongly agree. The majority of respondents $($ mean $=3.4)$ believed that email communication is cost effectiveness. According to descriptive analysis, 6 respondents rated as strongly disagree, 7 respondents rated as disagree, 26 respondents rated as neutral, 26 respondents rated as agree and 13 respondents rated as strongly agree.

The majority of respondents (mean=3.5) reported that employees in the maintenance department of Cement industry check their email consistently. According to descriptive analysis, 7 respondents rated as strongly disagree, 5 respondents rated as disagree, 27 respondents rated as neutral, 21 respondents rated as agree and 18 respondents rated as strongly agree. The majority of respondents $($ mean $=3.4$ ) believed that managers in the maintenance department of Cement industry are effective in corresponding with employees via email. According to descriptive analysis, 4 respondents rated as strongly disagree, 13 respondents rated as disagree, 20 respondents rated as neutral, 33 respondents rated as agree and 8 respondents rated as strongly agree. The majority of respondents $($ mean=3.4) believed that they can reach their manager directly via email. According to descriptive analysis, 6 respondents rated as strongly disagree, 9 respondents rated as disagree, 22 respondents rated as neutral, 27 respondents rated as agree and 14 respondents rated as strongly agree. The majority of respondents (mean=3.4) believed that managers in the maintenance department of Cement industry transfer useful information regarding their tasks and duties via email. According to descriptive analysis, 6 respondents rated as strongly disagree, 11 respondents rated as disagree, 16 respondents rated as neutral, 36 respondents rated as agree and 9 respondents rated as strongly agree. The majority of respondents (mean=3.6) believed that managers in the maintenance department of Cement industry forward department's monthly news and events via email. According to descriptive analysis, one respondent rated as strongly disagree, 10 respondents rated as disagree, 19 respondents rated as neutral, 36 respondents rated as agree and 12 respondents rated as strongly agree. The majority of respondents $($ mean $=3.5)$ believed that managers in the maintenance department of Cement industry forward organization's monthly news and events via email. According to descriptive analysis, 4 respondents rated as strongly disagree, 10 respondents rated as disagree, 20 respondents rated as neutral, 31 respondents rated as agree and 13 respondents rated as strongly agree.

Table 3-Email communication -Descriptive analysis

\begin{tabular}{|c|c|c|c|c|c|}
\hline No & Questions & Scales & Frequency & Percent & Mean \\
\hline \multirow{5}{*}{1} & \multirow{5}{*}{$\begin{array}{l}\text { Email communication is fast to } \\
\text { reach employees }\end{array}$} & Strongly disagree & 4 & 5.1 & \multirow{5}{*}{3.4} \\
\hline & & Disagree & 9 & 11.5 & \\
\hline & & Neutral & 27 & 34.6 & \\
\hline & & Agree & 28 & 35.9 & \\
\hline & & Strongly agree & 10 & 12.8 & \\
\hline \multirow{5}{*}{2} & \multirow{5}{*}{$\begin{array}{l}\text { Email communication is cost } \\
\text { effective }\end{array}$} & Strongly disagree & 6 & 7.7 & \multirow{5}{*}{3.4} \\
\hline & & Disagree & 7 & 9.0 & \\
\hline & & Neutral & 26 & 33.3 & \\
\hline & & Agree & 26 & 33.3 & \\
\hline & & Strongly agree & 13 & 16.7 & \\
\hline \multirow{4}{*}{3} & \multirow{4}{*}{ I consistently check my email } & Strongly disagree & 7 & 9.0 & \multirow{4}{*}{3.5} \\
\hline & & Disagree & 5 & 6.4 & \\
\hline & & Neutral & 27 & 34.6 & \\
\hline & & Agree & 21 & 26.9 & \\
\hline
\end{tabular}




\begin{tabular}{|c|c|c|c|c|c|}
\hline & & Strongly agree & 18 & 23.1 & \\
\hline \multirow{5}{*}{4} & \multirow{5}{*}{$\begin{array}{l}\text { My manager is effective in } \\
\text { corresponding with us via email }\end{array}$} & Strongly disagree & 4 & 5.1 & \multirow{5}{*}{3.4} \\
\hline & & Disagree & 13 & 16.7 & \\
\hline & & Neutral & 20 & 25.6 & \\
\hline & & Agree & 33 & 42.3 & \\
\hline & & Strongly agree & 8 & 10.3 & \\
\hline \multirow{5}{*}{5} & \multirow{5}{*}{$\begin{array}{l}\text { I can reach their manager directly } \\
\text { via email }\end{array}$} & Strongly disagree & 6 & 7.7 & \multirow{5}{*}{3.4} \\
\hline & & Disagree & 9 & 11.5 & \\
\hline & & Neutral & 22 & 28.2 & \\
\hline & & Agree & 27 & 34.6 & \\
\hline & & Strongly agree & 14 & 17.9 & \\
\hline \multirow{5}{*}{6} & \multirow{5}{*}{$\begin{array}{l}\text { My manager transfers useful } \\
\text { information regarding my tasks } \\
\text { and duties via email }\end{array}$} & Strongly disagree & 6 & 7.7 & \multirow{5}{*}{3.4} \\
\hline & & Disagree & 11 & 14.1 & \\
\hline & & Neutral & 16 & 20.5 & \\
\hline & & Agree & 36 & 46.2 & \\
\hline & & Strongly agree & 9 & 11.5 & \\
\hline \multirow{5}{*}{7} & \multirow{5}{*}{$\begin{array}{l}\text { My manager forwards our } \\
\text { department's monthly news and } \\
\text { events via email }\end{array}$} & Strongly disagree & 1 & 1.3 & \multirow{5}{*}{3.6} \\
\hline & & Disagree & 10 & 12.8 & \\
\hline & & Neutral & 19 & 24.4 & \\
\hline & & Agree & 36 & 46.2 & \\
\hline & & Strongly agree & 12 & 15.4 & \\
\hline \multirow{5}{*}{8} & \multirow{5}{*}{$\begin{array}{l}\text { My manager forwards our } \\
\text { organization's monthly news and } \\
\text { events via email }\end{array}$} & Strongly disagree & 4 & 5.1 & \multirow{5}{*}{3.5} \\
\hline & & Disagree & 10 & 12.8 & \\
\hline & & Neutral & 20 & 25.6 & \\
\hline & & Agree & 31 & 39.7 & \\
\hline & & Strongly agree & 13 & 16.7 & \\
\hline
\end{tabular}

\section{Notice Board}

As for notice board factor, it was found that the majority of respondents $($ mean $=3.5)$ reported that managers in the maintenance department of Cement industry are effectively publishing events via the notice board. According to descriptive analysis, 4 respondents rated as strongly disagree, 7 respondents rated as disagree, 23 respondents rated as neutral, 35 respondents rated as agree and 9 respondents rated as strongly agree. The majority of respondents (mean=3.5) reported that employees in the maintenance department of Cement industry read the notice board everyday. According to descriptive analysis, 4 respondents rated as strongly disagree, 9 respondents rated as disagree, 22 respondents rated as neutral, 30 respondents rated as agree and 13 respondents rated as strongly agree.
The majority of respondents (mean=3.2) reported that the maintenance department of Cement industry as seen announce holidays and vacant posts via the notice board. According to descriptive analysis, 11 respondents rated as strongly disagree, 9 respondents rated as disagree, 24 respondents rated as neutral, 21 respondents rated as agree and 13 respondents rated as strongly agree. The majority of respondents $($ mean=3.1) reported that the maintenance department of Cement industry announce promotions , wages and benefits via the notice board. According to descriptive analysis, 15 respondents rated as strongly disagree, 10 respondents rated as disagree, 15 respondents rated as neutral, 29 respondents rated as agree and 9 respondents rated as strongly agree. The majority of respondents $($ mean $=3.4)$ reported that managers in the 
maintenance department of Cement industry use the notice board very clearly so everyone can read it. According to descriptive analysis, 8 respondents rated as strongly disagree, 6 respondents rated as disagree, 24 respondents rated as neutral, 30 respondents rated as agree and 10 respondents rated as strongly agree.
The majority of respondents (mean=3.6) reported that managers in the maintenance department of Cement industry use the notice board in an attractive way so employees can notice and read it. According to descriptive analysis, 2 respondents rated as strongly disagree, 6 respondents rated as disagree, 24 respondents rated as neutral, 33 respondents rated as agree and 13 respondents rated as strongly agree.

Table 4-Notice Board-Descriptive analysis

\begin{tabular}{|c|c|c|c|c|c|}
\hline No & Questions & Scales & Frequency & Percent & Mean \\
\hline \multirow{5}{*}{1} & \multirow{5}{*}{$\begin{array}{l}\text { My manager is effectively } \\
\text { publishing events via the } \\
\text { notice board }\end{array}$} & Strongly disagree & 4 & 5.1 & \multirow{5}{*}{3.5} \\
\hline & & Disagree & 7 & 9.0 & \\
\hline & & Neutral & 23 & 29.5 & \\
\hline & & Agree & 35 & 44.9 & \\
\hline & & Strongly agree & 9 & 11.5 & \\
\hline \multirow{5}{*}{2} & \multirow{5}{*}{$\begin{array}{l}\text { I read the notice board } \\
\text { everyday }\end{array}$} & Strongly disagree & 4 & 5.1 & \multirow{5}{*}{3.5} \\
\hline & & Disagree & 9 & 11.5 & \\
\hline & & Neutral & 22 & 28.2 & \\
\hline & & Agree & 30 & 38.5 & \\
\hline & & Strongly agree & 13 & 16.7 & \\
\hline \multirow{5}{*}{3} & \multirow{5}{*}{$\begin{array}{l}\text { Maintenance department } \\
\text { announce holidays and vacant } \\
\text { posts via the notice board }\end{array}$} & Strongly disagree & 11 & 14.1 & \multirow{5}{*}{3.2} \\
\hline & & Disagree & 9 & 11.5 & \\
\hline & & Neutral & 24 & 30.8 & \\
\hline & & Agree & 21 & 26.9 & \\
\hline & & Strongly agree & 13 & 16.7 & \\
\hline \multirow{5}{*}{4} & \multirow{5}{*}{$\begin{array}{l}\text { Maintenance department } \\
\text { announces promotions, wages } \\
\text { and benefits via the notice } \\
\text { board }\end{array}$} & Strongly disagree & 15 & 19.2 & \multirow{5}{*}{3.1} \\
\hline & & Disagree & 10 & 12.8 & \\
\hline & & Neutral & 15 & 19.2 & \\
\hline & & Agree & 29 & 37.2 & \\
\hline & & Strongly agree & 9 & 11.5 & \\
\hline \multirow{5}{*}{5} & \multirow{5}{*}{$\begin{array}{l}\text { My manager uses the notice } \\
\text { board very clearly so everyone } \\
\text { can read it }\end{array}$} & Strongly disagree & 8 & 10.3 & \multirow{5}{*}{3.4} \\
\hline & & Disagree & 6 & 7.7 & \\
\hline & & Neutral & 24 & 30.8 & \\
\hline & & Agree & 30 & 38.5 & \\
\hline & & Strongly agree & 10 & 12.8 & \\
\hline \multirow{5}{*}{6} & \multirow{5}{*}{$\begin{array}{l}\text { My manager uses the notice } \\
\text { board in an attractive way so } \\
\text { employees can notice and read } \\
\text { it }\end{array}$} & Strongly disagree & 2 & 2.6 & \multirow{5}{*}{3.6} \\
\hline & & Disagree & 6 & 7.7 & \\
\hline & & Neutral & 24 & 30.8 & \\
\hline & & Agree & 33 & 42.3 & \\
\hline & & Strongly agree & 13 & 16.7 & \\
\hline
\end{tabular}




\section{Text Messaging}

As for text messaging, it was found that the majority of respondents (mean=3.3) reported that managers in the maintenance department of Cement industry provide employees with necessary information regarding their job via text messaging. According to descriptive analysis, 10 respondents rated as strongly disagree, 5 respondents rated as disagree, 25 respondents rated as neutral, 27 respondents rated as agree and 11 respondents rated as strongly agree. The majority of respondents (mean=3.4) reported that in case employees are not visible in the maintenance department of Cement industry their manager texts them. According to descriptive analysis, 5 respondents rated as strongly disagree, 6 respondents rated as disagree, 30 respondents rated as neutral, 27 respondents rated as agree and 10 respondents rated as strongly agree. The majority of respondents $($ mean $=3.7)$ reported that employees in maintenance department of Cement industry use prefer to be texted rather than phone call during their work. According to descriptive analysis, one respondent rated as strongly disagree, 4 respondents rated as disagree, 27 respondents rated as neutral, 28 respondents rated as agree and 18 respondents rated as strongly agree. The majority of respondents (mean=3.4) reported that employees in the maintenance department of Cement industry prefer to be texted rather than called by phone while they are home. According to descriptive analysis, 5 respondents rated as strongly disagree, 5 respondents rated as disagree, 33 respondents rated as neutral, 22 respondents rated as agree and 13 respondents rated as strongly agree. The majority of respondents $($ mean $=3.0)$ reported that employees in the maintenance department of Cement industry communicate with their co-workers via text messaging. According to descriptive analysis, 13 respondents rated as strongly disagree, 9 respondents rated as disagree, 32 respondents rated as neutral, 16 respondents rated as agree and 8 respondents rated as strongly agree.

Table 5- Text Messaging -Descriptive analysis

\begin{tabular}{|c|c|c|c|c|c|}
\hline No & Questions & Scales & Frequency & Percent & Mean \\
\hline \multirow{5}{*}{1} & \multirow{5}{*}{$\begin{array}{l}\text { My manager provides me with } \\
\text { necessary information regarding } \\
\text { my job via text messaging }\end{array}$} & Strongly disagree & 10 & 12.8 & \multirow{5}{*}{3.3} \\
\hline & & Disagree & 5 & 6.4 & \\
\hline & & Neutral & 25 & 32.1 & \\
\hline & & Agree & 27 & 34.6 & \\
\hline & & Strongly agree & 11 & 14.1 & \\
\hline \multirow{5}{*}{2} & \multirow{5}{*}{$\begin{array}{l}\text { In case I am not visible, my } \\
\text { manager texts me }\end{array}$} & Strongly disagree & 5 & 6.4 & \multirow{5}{*}{3.4} \\
\hline & & Disagree & 6 & 7.7 & \\
\hline & & Neutral & 30 & 38.5 & \\
\hline & & Agree & 27 & 34.6 & \\
\hline & & Strongly agree & 10 & 12.8 & \\
\hline \multirow{5}{*}{3} & \multirow{5}{*}{$\begin{array}{l}\text { I prefer to be texted rather than } \\
\text { called by phone during my work }\end{array}$} & Strongly disagree & 1 & 1.3 & \multirow{5}{*}{3.7} \\
\hline & & Disagree & 4 & 5.1 & \\
\hline & & Neutral & 27 & 34.6 & \\
\hline & & Agree & 28 & 35.9 & \\
\hline & & Strongly agree & 18 & 23.1 & \\
\hline \multirow{5}{*}{4} & \multirow{5}{*}{$\begin{array}{l}\text { I prefer to be texted rather than } \\
\text { called by phone while I am home }\end{array}$} & Strongly disagree & 5 & 6.4 & \multirow{5}{*}{3.4} \\
\hline & & Disagree & 5 & 6.4 & \\
\hline & & Neutral & 33 & 42.3 & \\
\hline & & Agree & 22 & 28.2 & \\
\hline & & Strongly agree & 13 & 16.7 & \\
\hline \multirow{2}{*}{5} & \multirow{2}{*}{$\begin{array}{l}\text { I communicate with my co-workers } \\
\text { via text messaging }\end{array}$} & Strongly disagree & 13 & 16.7 & \\
\hline & & Disagree & 9 & 11.5 & \\
\hline
\end{tabular}




\begin{tabular}{|l|l|l|l|l|l|}
\hline \multirow{2}{*}{} & Neutral & 32 & 41.0 & 3.0 \\
\cline { 3 - 4 } & Agree & 16 & 20.5 \\
\cline { 2 - 5 } & Strongly agree & 8 & 10.3 \\
\hline
\end{tabular}

\section{Site visits}

As for site visits factor, it was found that the majority of respondents $($ mean=3.6) reported that managers in the maintenance department of Cement industry walk in to check and control work activities. According to descriptive analysis, 2 respondents rated as strongly disagree, 4 respondents rated as disagree, 30 respondents rated as neutral, 33 respondents rated as agree and 9 respondents rated as strongly agree. The majority of respondents (mean=3.5) reported that managers in the maintenance department of Cement industry are visible. According to descriptive analysis, 3 respondents rated as strongly disagree, 6 respondents rated as disagree, 28 respondents rated as neutral, 31 respondents rated as agree and 10 respondents rated as strongly agree. The majority of respondents (mean=3.5) reported that managers in the maintenance department of Cement industry deal with issues by visiting the department. According to descriptive analysis, 3 respondents rated as strongly disagree, 4 respondents rated as disagree, 32 respondents rated as neutral, 27 respondents rated as agree and 12 respondents rated as strongly agree. The majority of respondents (mean=3.3) reported that managers in the maintenance department of Cement industry have skills and try to learn about issues ahead of time before they become a problem.
According to descriptive analysis, 4 respondents rated as strongly disagree, 5 respondents rated as disagree, 38 respondents rated as neutral, 22 respondents rated as agree and 9 respondents rated as strongly agree. The majority of respondents $($ mean $=3.3)$ reported that managers in the maintenance department of Cement industry check daily activities and control all business processes. According to descriptive analysis, 6 respondents rated as strongly disagree, 9 respondents rated as disagree, 27 respondents rated as neutral, 26 respondents rated as agree and 10 respondents rated as strongly agree. The majority of respondents (mean=3.3) reported that managers in the maintenance department of Cement industry motivate employees while they visit them on the site. According to descriptive analysis, 6 respondents rated as strongly disagree, 10 respondents rated as disagree, 18 respondents rated as neutral, 38 respondents rated as agree and 6 respondents rated as strongly agree. The majority of respondents $($ mean $=3.8)$ reported that managers in the maintenance department of Cement industry bring new creative ideas by visiting the site. According to descriptive analysis, 2 respondents rated as strongly disagree, 4 respondents rated as disagree, 19 respondents rated as neutral, 37 respondents rated as agree and 16 respondents rated as strongly agree.

Table 6-Site visits -Descriptive analysis

\begin{tabular}{|c|c|c|c|c|c|}
\hline No & Questions & Scales & Frequency & Percent & Mean \\
\hline \multirow{5}{*}{1} & \multirow{5}{*}{$\begin{array}{l}\text { My manager always walks in to } \\
\text { check and control work } \\
\text { activities }\end{array}$} & Strongly disagree & 2 & 2.6 & \multirow{5}{*}{3.6} \\
\hline & & Disagree & 4 & 5.1 & \\
\hline & & Neutral & 30 & 38.5 & \\
\hline & & Agree & 33 & 42.3 & \\
\hline & & Strongly agree & 9 & 11.5 & \\
\hline \multirow{5}{*}{2} & \multirow{5}{*}{$\begin{array}{l}\text { My manager is visible in our } \\
\text { department }\end{array}$} & Strongly disagree & 3 & 3.8 & \multirow{5}{*}{3.5} \\
\hline & & Disagree & 6 & 7.7 & \\
\hline & & Neutral & 28 & 35.9 & \\
\hline & & Agree & 31 & 39.7 & \\
\hline & & Strongly agree & 10 & 12.8 & \\
\hline \multirow{4}{*}{3} & \multirow{4}{*}{$\begin{array}{l}\text { My manager deals with issues } \\
\text { by visiting the department }\end{array}$} & Strongly disagree & 3 & 3.8 & \multirow{4}{*}{3.5} \\
\hline & & Disagree & 4 & 5.1 & \\
\hline & & Neutral & 32 & 41.0 & \\
\hline & & Agree & 27 & 34.6 & \\
\hline
\end{tabular}




\begin{tabular}{|c|c|c|c|c|c|}
\hline & & Strongly agree & 12 & 15.4 & \\
\hline \multirow{5}{*}{4} & \multirow{5}{*}{$\begin{array}{l}\text { My manager has skills and tries } \\
\text { to learn about issues ahead of } \\
\text { time before they become a } \\
\text { problem }\end{array}$} & Strongly disagree & 4 & 5.1 & \multirow{5}{*}{3.3} \\
\hline & & Disagree & 5 & 6.4 & \\
\hline & & Neutral & 38 & 48.7 & \\
\hline & & Agree & 22 & 28.2 & \\
\hline & & Strongly agree & 9 & 11.5 & \\
\hline \multirow{5}{*}{5} & \multirow{5}{*}{$\begin{array}{l}\text { My manager checks daily } \\
\text { activities and controls all } \\
\text { business processes }\end{array}$} & Strongly disagree & 6 & 7.7 & \multirow{5}{*}{3.3} \\
\hline & & Disagree & 9 & 11.5 & \\
\hline & & Neutral & 27 & 34.6 & \\
\hline & & Agree & 26 & 33.3 & \\
\hline & & Strongly agree & 10 & 12.8 & \\
\hline \multirow{5}{*}{6} & \multirow{5}{*}{$\begin{array}{l}\text { My manager motivates me } \\
\text { while he visits us on the site }\end{array}$} & Strongly disagree & 6 & 7.7 & \multirow{5}{*}{3.4} \\
\hline & & Disagree & 10 & 12.8 & \\
\hline & & Neutral & 18 & 23.1 & \\
\hline & & Agree & 38 & 48.7 & \\
\hline & & Strongly agree & 6 & 7.7 & \\
\hline \multirow{5}{*}{7} & \multirow{5}{*}{$\begin{array}{l}\text { My manager brings new } \\
\text { creative ideas by visiting the site }\end{array}$} & Strongly disagree & 2 & 2.6 & \multirow{5}{*}{3.8} \\
\hline & & Disagree & 4 & 5.1 & \\
\hline & & Neutral & 19 & 24.4 & \\
\hline & & Agree & 37 & 47.4 & \\
\hline & & Strongly agree & 16 & 20.5 & \\
\hline
\end{tabular}

\section{Face to face communication}

As for face-to-face communication factor, it was found that the majority of respondents (mean=3.7) believed that face to face meetings enable employees to make a quick decision. According to descriptive analysis, 2 respondents rated as strongly disagree, 4 respondents rated as disagree, 22 respondents rated as neutral, 38 respondents rated as agree and 12 respondents rated as strongly agree. The majority of respondents (mean=3.6) believed that face to face meetings enable employees to socialize and interact with each other. According to descriptive analysis, 4 respondents rated as strongly disagree, 7 respondents rated as disagree, 20 respondents rated as neutral, 31 respondents rated as agree and 16 respondents rated as strongly agree. The majority of respondents (mean=3.6) believed that face to face meetings enable employees to quickly build relationships, trust and improve lasting business relationships. According to descriptive analysis, 4 respondents rated as strongly disagree, 6 respondents rated as disagree, 18 respondents rated as neutral, 43 respondents rated as agree and 7 respondents rated as strongly agree. The majority of respondents (mean=3.6) believed that face to face meetings boosts efficiency. According to descriptive analysis, 2 respondents rated as strongly disagree, 4 respondents rated as disagree, 20 respondents rated as neutral, 39 respondents rated as agree and 13 respondents rated as strongly agree. The majority of respondents (mean=3.6) believed that face to face meetings boost creativity as the overall energy will be higher so you can brainstorm and solve a multitude of problems at one time. According to descriptive analysis, 1 respondent rated as strongly disagree, 9 respondents rated as disagree, 25 respondents rated as neutral, 28 respondents rated as agree and 15 respondents rated as strongly agree.

Table 7-Face to face communication-Descriptive analysis

\begin{tabular}{|l|l|l|l|l|l|}
\hline No & Questions & Scales & Frequency & Percent & Mean \\
\hline \multirow{2}{*}{$\mathbf{1}$} & Face to face meetings enable & Strongly disagree & 2 & 2.6 & \\
\cline { 3 - 6 } & us to make a quick decision & Disagree & 4 & 5.1 & \\
\hline
\end{tabular}




\begin{tabular}{|c|c|c|c|c|c|}
\hline & & Neutral & 22 & 28.2 & \multirow[t]{3}{*}{3.7} \\
\hline & & Agree & 38 & 48.7 & \\
\hline & & Strongly agree & 12 & 15.4 & \\
\hline \multirow{5}{*}{2} & \multirow{5}{*}{$\begin{array}{l}\text { Face to face meetings enable } \\
\text { us to socialize and interact } \\
\text { with each other }\end{array}$} & Strongly disagree & 4 & 5.1 & \multirow{5}{*}{3.6} \\
\hline & & Disagree & 7 & 9.0 & \\
\hline & & Neutral & 20 & 25.6 & \\
\hline & & Agree & 31 & 39.7 & \\
\hline & & Strongly agree & 16 & 20.5 & \\
\hline \multirow{5}{*}{3} & \multirow{5}{*}{$\begin{array}{l}\text { It enables us to quickly build } \\
\text { relationships, trust and } \\
\text { improve lasting business } \\
\text { relationships }\end{array}$} & Strongly disagree & 4 & 5.1 & \multirow{5}{*}{3.6} \\
\hline & & Disagree & 6 & 7.7 & \\
\hline & & Neutral & 18 & 23.1 & \\
\hline & & Agree & 43 & 55.1 & \\
\hline & & Strongly agree & 7 & 9.0 & \\
\hline \multirow{5}{*}{4} & \multirow{5}{*}{$\begin{array}{l}\text { Face to face communication } \\
\text { boosts efficiency }\end{array}$} & Strongly disagree & 2 & 2.6 & \multirow{5}{*}{3.7} \\
\hline & & Disagree & 4 & 5.1 & \\
\hline & & Neutral & 20 & 25.6 & \\
\hline & & Agree & 39 & 50.0 & \\
\hline & & Strongly agree & 13 & 16.7 & \\
\hline \multirow{5}{*}{5} & \multirow{5}{*}{$\begin{array}{l}\text { It boosts creativity as the } \\
\text { overall energy will be higher } \\
\text { so you can brainstorm and } \\
\text { solve a multitude of } \\
\text { problems at one time }\end{array}$} & Strongly disagree & 1 & 1.3 & \multirow{5}{*}{3.6} \\
\hline & & Disagree & 9 & 11.5 & \\
\hline & & Neutral & 25 & 32.1 & \\
\hline & & Agree & 28 & 35.9 & \\
\hline & & Strongly agree & 15 & 19.2 & \\
\hline
\end{tabular}

\section{Network communication}

As for network communication, it was found that the majority of respondents (mean=3.4) reported that employees in the maintenance department of Cement industry openly communicate with everyone in other departments at any time regardless of rank or position. According to descriptive analysis, 3 respondents rated as strongly disagree, 8 respondents rated as disagree, 30 respondents rated as neutral, 27 respondents rated as agree and 10 respondents rated as strongly agree. The majority of respondents (mean=3.6) reported that employees in the maintenance department of Cement industry feel comfortable communicating with everyone in their chain of command. According to descriptive analysis, 3 respondents rated as strongly disagree, 5 respondents rated as disagree, 27 respondents rated as neutral, 31 respondents rated as agree and 12 respondents rated as strongly agree. The majority of respondents (mean=3.3) reported that employees in the maintenance department of Cement industry can share opinions, suggestions and ideas with other departments. According to descriptive analysis, 5 respondents rated as strongly disagree, 9 respondents rated as disagree, 32 respondents rated as neutral, 24 respondents rated as agree and 8 respondents rated as strongly agree. The majority of respondents (mean=3.0) reported that the maintenance department of Cement industry shares essential information with other departments. According to descriptive analysis, 9 respondents rated as strongly disagree, 10 respondents rated as disagree, 35 respondents rated as neutral, 21 respondents rated as agree and 3 respondents rated as strongly agree. The majority of respondents $($ mean=3.0) reported that other departments share essential information with the maintenance department of Cement industry. According to descriptive analysis, 2 respondents rated as strongly disagree, 9 respondents rated as disagree, 28 respondents rated as neutral, 29 respondents rated as agree and 10 respondents rated as strongly agree. The majority of respondents $($ mean $=3.6)$ reported that information shared by employees in other departments often reflect their own personal 
interests. According to descriptive analysis, 4 respondents rated as strongly disagree, 5 respondents rated as disagree,
24 respondents rated as neutral, 34 respondents rated as agree and 11 respondents rated as strongly agree.

Table 8-Network communication-Descriptive analysis

\begin{tabular}{|c|c|c|c|c|c|}
\hline No & Questions & Scales & Frequency & Percent & Mean \\
\hline \multirow{5}{*}{1} & \multirow{5}{*}{$\begin{array}{l}\text { I openly communicate with } \\
\text { everyone in other departments at } \\
\text { any time regardless of rank or } \\
\text { position }\end{array}$} & Strongly disagree & 3 & 3.8 & \multirow{5}{*}{3.4} \\
\hline & & Disagree & 8 & 10.3 & \\
\hline & & Neutral & 30 & 38.5 & \\
\hline & & Agree & 27 & 34.6 & \\
\hline & & Strongly agree & 10 & 12.8 & \\
\hline \multirow{5}{*}{2} & \multirow{5}{*}{$\begin{array}{l}\text { I feel comfortable communicating } \\
\text { with everyone in my chain of } \\
\text { command }\end{array}$} & Strongly disagree & 3 & 3.8 & \multirow{5}{*}{3.6} \\
\hline & & Disagree & 5 & 6.4 & \\
\hline & & Neutral & 27 & 34.6 & \\
\hline & & Agree & 31 & 39.7 & \\
\hline & & Strongly agree & 12 & 15.4 & \\
\hline \multirow{5}{*}{3} & \multirow{5}{*}{$\begin{array}{l}\text { I can share opinions, suggestions } \\
\text { and ideas with other departments }\end{array}$} & Strongly disagree & 5 & 6.4 & \multirow{5}{*}{3.3} \\
\hline & & Disagree & 9 & 11.5 & \\
\hline & & Neutral & 32 & 41.0 & \\
\hline & & Agree & 24 & 30.8 & \\
\hline & & Strongly agree & 8 & 10.3 & \\
\hline \multirow{5}{*}{4} & \multirow{5}{*}{$\begin{array}{l}\text { My department shares essential } \\
\text { information with other } \\
\text { departments. }\end{array}$} & Strongly disagree & 9 & 11.5 & \multirow{5}{*}{3.0} \\
\hline & & Disagree & 10 & 12.8 & \\
\hline & & Neutral & 35 & 44.9 & \\
\hline & & Agree & 21 & 26.9 & \\
\hline & & Strongly agree & 3 & 3.8 & \\
\hline \multirow{5}{*}{5} & \multirow{5}{*}{$\begin{array}{l}\text { Other departments share } \\
\text { essential information with my } \\
\text { department. }\end{array}$} & Strongly disagree & 2 & 2.6 & \multirow{5}{*}{3.5} \\
\hline & & Disagree & 9 & 11.5 & \\
\hline & & Neutral & 28 & 35.9 & \\
\hline & & Agree & 29 & 37.2 & \\
\hline & & Strongly agree & 10 & 12.8 & \\
\hline \multirow{5}{*}{6} & \multirow{5}{*}{$\begin{array}{l}\text { The information that is shared by } \\
\text { employees in other departments } \\
\text { often reflects their own personal } \\
\text { interests. }\end{array}$} & Strongly disagree & 4 & 5.1 & \multirow{5}{*}{3.6} \\
\hline & & Disagree & 5 & 6.4 & \\
\hline & & Neutral & 24 & 30.8 & \\
\hline & & Agree & 34 & 43.6 & \\
\hline & & Strongly agree & 11 & 14.1 & \\
\hline
\end{tabular}

\section{DISCUSSION}

This section discusses the results of the data gathered by questionnaires during this study in relation to the current literature. The findings in the following section are divided into seven categories; team meetings, email, notice board, text messaging, site visits, face to face and network communication. The findings suggest that there are more positive aspects than negative aspects; therefore, this section emphasizes some of the key subjects to emerge from the respondents' view of internal communication and its impact on organizational performance. 
The current management at Cement industry is supporting management teams to improve in communication with their teams (in cooperation with HR, training and so on) as seen in appendix (B). The research findings were supported that current management at Cement industry implementing team meetings effectively. According to the data analysis the researcher was able to find out that the majority of respondents reported that team meetings are considered time consuming, team meetings are very essential for enhancing organizational performance, team meetings provide opportunities for employees to discuss and provide feedback and give their opinions, manager in the maintenance department of Cement industry has enough communication skills, manager in the maintenance department of Cement industry does team meetings every day, manager in the maintenance department of Cement industry involves all employees in team meetings, manager in the maintenance department of Cement industry effectively communicates with the team, manager in the maintenance department of Cement industry gives employees an opportunity to participate in decision making, employees as a team in the maintenance department of Cement industry are providing ideas to enhance performance, employees as a team in the maintenance department of Cement industry are committed to team meetings and manager in the maintenance department of Cement industry is committed to team meetings.

The current management at Cement industry is creating and using online- printed communications tools, organizing regular events as seen in appendix (B). The research findings were supported that current management at Cement industry using online tools for internal communication. The findings were most of respondents reported that email communication is considered a fast tool to reach employees in the maintenance department of Cement industry, email communication is cost effectiveness, employees in the maintenance department of Cement industry check their email consistently, managers in the maintenance department of Cement industry are effective in corresponding with employees via email, employees at cement industry are able to reach their manager directly via email, managers in the maintenance department of Cement industry transfer useful information regarding their tasks and duties via email, managers in the maintenance department of Cement industry forward department's monthly news and events via email, managers in the maintenance department of Cement industry forward organization's monthly news and events via email, managers in the maintenance department of Cement and all of the maintenance department's employees have an email address.
In terms of notice board communication, the researcher was not able to find any link between company's' standard as a fact of internal communication method and respondent's perception as research findings. At this point the researcher was able to point out the gap between this study and the fact of internal communication at maintenance department in Cement industry. As the findings of the study were as follow; the majority of respondents reported that managers in the maintenance department of Cement industry are effectively publishing events via the notice board, employees in the maintenance department of Cement industry read the notice board every day, the maintenance department of Cement industry, the maintenance department of Cement industry announce promotions , wages and benefits via the notice board, managers in the maintenance department of Cement industry use the notice board very clearly so everyone can read it and managers in the maintenance department of Cement industry use the notice board in an attractive way so employees can notice and read it.

Text messaging communication, meanwhile, the researcher was not able to find a connection between research findings as respondents' perception and standard of Cement industry as a fact of internal communication. According to the research findings the researcher was able to point out the gap between the research outcome and the fact of internal communication at cement industry. The findings were as follow; The majority of respondents reported that managers in the maintenance department of Cement industry provide employees with necessary information regarding their job via text messaging, in case employees are not visible in the maintenance department of Cement industry their manager texts them, employees in maintenance department of Cement industry use prefer to be texted rather than phone call during their work, employees in the maintenance department of Cement industry prefer to be texted rather than called by phone while they are home, and employees in the maintenance department of Cement industry communicate with their co-workers via text messaging.

When it comes to site visit communication method, the researcher was not able to find a link between respondent's perception in this research and the fact of internal communication at cement industry. According to the findings the researcher was able to find out the gap between site visit communication between perception and the fact as follow; The majority of respondents reported that managers in the maintenance department of Cement industry walk in to check and control work activities, managers in the maintenance department of Cement industry are visible, managers in the maintenance department of Cement industry deal with issues by visiting the department, managers in the maintenance department of Cement 
industry have skills and try to learn about issues ahead of time before they become a problem, managers in the maintenance department of Cement industry check daily activities and control all business processes, managers in the maintenance department of Cement industry motivate employees while they visit them on the site, managers in the maintenance department of Cement industry bring new creative ideas by visiting the site.

Concerns of face-to-face communication method, also, was not found in the standard of internal communication at cement industry. Accordingly, the researcher was able to point out the gap between face-to-face communication method as a fact and respondents' perception according to the research findings. The findings were as follow; the majority of respondents reported that face to face meetings enable employees to make a quick decision, face to face meetings enable employees to socialize and interact with each other, face to face meetings enable employees to quickly build relationships, trust and improve lasting business relationships, face to face meetings boosts efficiency and face to face meetings boost creativity as the overall energy will be higher so you can brainstorm and solve a multitude of problems at one time.

The current management at Cement industry is establishing a regular, transparent communication with all employees covering the entire organization as seen in appendix (B). The research findings were supported that current management at Cement industry implementing network communication effectively. According to the data analysis the researcher was able to find out; the majority of respondents reported that employees in the maintenance department of Cement industry openly communicate with everyone in other departments at any time regardless of rank or position, employees in the maintenance department of Cement industry feel comfortable communicating with everyone in their chain of command, employees in the maintenance department of Cement industry can share opinions, suggestions and ideas with other departments, the maintenance department of Cement industry shares essential information with other departments, other departments share essential information with the maintenance department of Cement industry, information shared by employees in other departments often reflect their own personal interests, most interdepartmental meetings are useful for obtaining information and social media (Facebook, Twitter, etc.) will have a positive impact on departments communication.

\section{CONCLUSION}

The research aim is to investigate the impact of internal communication on organizational performance in Cement Company. After analyzing data gathered in the maintenance department in Cement Company, the researcher was able to gain a deeper understanding of internal communication factors that influence organizational performance.

In order to attain an effective internal communication, it is necessary to recognize and understand the type of information which will be communicated, from whom the information is transmitted and to whom the information is pointed.

In this study, the researcher has examined seven variables: team meetings, email communication, network communication, notice board communication, face to face, site visits and text messaging communication as independent variables, and organizational performance as the dependent variable. The researcher came to conclude that three factors (email communication, team meetings and network communication) are used effectively at cement industry, on the other hand four internal communication factors such us (face to face communication, notice board communication, site visits communication and text messaging communication) have not been implemented yet by comparing respondents' perception and the fact of internal communication standard. Therefore, the researcher was able to point out the gap between the fact of internal communication at cement industry and respondents' perception. It is essential to highlight that internal communication should not be considered as a project that is started up at certain time and then ends and is forgotten. Internal communication is an ongoing process which has no beginning or ending (Schipper, 2006).In conclusion, the findings obtained in this study have assisted in informing the complex relationship between internal communication and organizational performance.

\section{REFERENCES}

[1] Kalogiannidis, S. (2020). Impact of Effective Business Communication on Employee Performance. European Journal of Business and Management Research, 5(6).

[2] Flynn, C., Olson, J., \& Reinhardt, M. (2020). Self-regulated learning in online graduate business communication courses: a qualitative inquiry. Business and Professional Communication Quarterly, 83(1), 80-95.

[3] Abdullah, N. N., \& Othman, M. B. (2019). Effects of Intellectual Capital on the Performance of Malaysian Food and Beverage Small and Medium-Sized Enterprises. International Journal of Civil Engineering and Technology (IJCIET), 10(2), 135-143.

[4] Anwar, G., \& Abdullah, N. N. (2021). Inspiring future entrepreneurs: The effect of experiential learning on the 
entrepreneurial intention at higher education. International Journal of English Literature and Social Sciences, 6.

[5] Gardi, B., Hamawandy, N. M., Vian Sulaiman Hama Saeed, R. M. A., Sulaiman, A. A., Mahmood, S. A., \& Al-Kake, F. A. (2020). The Effect of Capital Competence on the Profitability of Development and Investment Banks in Turkey. Solid State Technology, 63(6), 12571-12583.

[6] Prabhu, M., Nambirajan, T., \& Abdullah, N. N. (2020). Operating competitive priorities of manufacturing firms: An analytical study. Journal of Industrial Engineering and Management, 13(1), 38-55.

[7] Anwar, G., \& Shukur, I. (2015). The Impact of Training and Development on Job Satisfaction: A Case Study of Private Banks in Erbil. International Journal of Social Sciences \& Educational Studies, 2(1), 65.

[8] Sultan, K., Ahmed, R. R., Jafar, R., Murtaza, M. M., \& Gardi, B. (2020). Corporate Financial Policy and Its Impact On Sustainable Capital Structure: Empirical Evidence From Textile Firms Of Pakistan.

[9] Abdullah, N. N., \& Othman, M. (2015). Disaster Management: Empirical Study of 2009 Jeddah Flood. Abdullah, NN \& Othman, M.(2015). Disaster Management: Empirical Study of, 1083-1087.

[10] Gardi, B. (2021). Investigating the effects of Financial Accounting Reports on Managerial Decision Making in Small and Medium-sized Enterprises. Turkish Journal of Computer and Mathematics Education (TURCOMAT), 12(10), 2134-2142

[11] Anwar, G., \& Shukur, I. (2015). Job satisfaction and employee turnover intention: A case study of private hospital in Erbil. International Journal of Social Sciences \& Educational Studies, 2(1), 73.

[12] Ismael, N. B., Sorguli, S., Aziz, H. M., Sabir, B. Y., Hamza, P. A., Gardi, B., \& Al-Kake, F. R. A. (2021). The Impact of COVID-19 on Small and Medium-Sized Enterprises in Iraq. Annals of the Romanian Society for Cell Biology, 24962505.

[13] Anwar, G., \& Shukur, I. (2015). the impact of recruitment and selection on job satisfaction: Evidence from private school in Erbil. International Journal of Social Sciences \& Educational Studies, 1(3), 4-13.

[14] Gardi, B. (2021). The effects of computerized accounting system on auditing process: a case study from northern Iraq. Available at SSRN 3838327

[15] Anwar, G., \& Abd Zebari, B. (2015). The Relationship between Employee Engagement and Corporate Social Responsibility: A Case Study of Car Dealership in Erbil, Kurdistan. International Journal of Social Sciences \& Educational Studies, 2(2), 45.

[16] Anwar, G., \& Surarchith, N. K. (2015). Factors Affecting Shoppers' Behavior in Erbil, Kurdistan-Iraq. International Journal of Social Sciences \& Educational Studies, 1(4), 10.

[17] Othman, B. J., Al-Kake, F., Diah, M. L. M., Othman, B., \& Hasan, N. M. (2019). This study examines the antecedents and the effects of knowledge management and information technology in the manufacturing industry. International Journal of Psychosocial Rehabilitation, 23(02).
[18] Khan, S. \& Abdullah, N. N. (2019). The effect of ATM service quality on customer's satisfaction and loyalty: an empirical analysis. RJOAS, 5(89): DOI 10.18551/rjoas.2019-05.2

[19] Anwar, G., \& Shukur, I. (2015). The Impact of Service Quality Dimensions on Students' Satisfaction. International Journal of Social Sciences \& Educational Studies, 76.

[20] Othman, B. J., Al-Kake, F., Diah, M. L. M., Othman, B., Hussein, S., \& Hasan, N. M. (2019). Impact of the foreign direct investment on the economy of the United Kingdom. International Journal of Psychosocial Rehabilitation, 23(02).

[21] Anwar, K. (2017). Analyzing the conceptual model of service quality and its relationship with guests'satisfaction: A Study of Hotels In Erbil. The International Journal of Accounting and Business Society, 25(2), 1-16

[22] Anwar, K. (2016). Comparison between cost leadership and differentiation strategy in agricultural businesses. Custos $\mathrm{E}$ Agronegocio on Line, 12(2), 212-231.

[23] Abdullah, M. S., Toycan, M., \& Anwar, K. (2017). The cost readiness of implementing e-learning. CUSTOS E AGRONEGOCIO ON LINE, 13(2), 156-175.

[24] Anwar, K., \& Balcioglu, H. (2016). The relationship between transformational leadership characteristics and effectiveness: A case study of construction companies in Erbil. International Journal of Science Technology and Management, 5(2), 250-256.

[25] Abdullah, N. N., \& Abdul Rahman, M. (2015). The Degree of Openness in Turkey's Public Expenditure. International Journal of Administration and Governance, 12(1), 8-12.

[26] Anwar, K. (2017). The Role of Effective Leadership in Crisis Management: Study of Private Companies in Kurdistan. Qalaai Zanist Scientific Journal, 2(4), 326-338.

[27] Hameed, A. A., \& Anwar, K. (2018). Analyzing the Relationship between Intellectual Capital and Organizational Performance: A Study of Selected Private Banks in Kurdistan. International Journal of Social Sciences \& Educational Studies, 4(4), 39.

[28] Damit, D. H. D. A., Harun, A., Martin, D., Othman, B., \& Ahmad, H. (2019). What makes a non-Muslim purchase halal food in a Muslim country? An application of theory of planned behaviour. Management Science Letters, 9(12), 2029-2038.

[29] Anwar, K., \& Ghafoor, C. (2017). Knowledge management and organizational performance: A study of private universities in Kurdistan. International Journal of Social Sciences \& Educational Studies, 4(2), 53.

[30] Prabhu, M., Thangasamy, N., \& Nawzad Abdullah, N. (2020). Analytical review on competitive priorities for operations under manufacturing firms. Journal of Industrial Engineering and Management, 13(1), 38-55.

[31] Anwar, K., \& Climis, R. (2017). Analyzing the relationship between types of advertisement and customer choice: a study of retailer stores in erbil. The International Journal of Accounting and Business Society, 25(2), 43-52.

[32] Anwar, K. (2017). Factors Affecting Stock Exchange Investment In Kurdistan. The International Journal of Accounting and Business Society, 25(1), 32-37. 
[33] rabhu, M., Abdullah, N. N. \& Mohan, M. G. (2019). An Empirical Study on the Satisfaction Level of National and International Tourists towards Natural Attractions in Kurdistan. African Journal of Hospitality, Tourism and Leisure, 8 (2). 1-8

[34] Anwar, K., \& Qadir, G. H. (2017). A Study of the Relationship between Work Engagement and Job Satisfaction in Private Companies in Kurdistan. International Journal of Advanced Engineering, Management and Science, 3(12), 239944.

[35] Abdullah, NN \& Rahman, MFA (2015). The Use of Deliberative Democracy in Public Policy Making Process. Public Policy and Administration Research, 5(3), 221-229.

[36] Anwar, K. Leading Construction Project Teams: The Effectiveness of Transformational Leadership in Dynamic Work Environments in Kurdistan. International Journal of Advanced Engineering, Management and Science, 3(10), 239925.

[37] Abdullah, N. N. (2019). Probing the Level of Satisfaction towards the Motivation Factors of Tourism in Kurdistan Region. Scholars Journal of Economics, Business and Management, 5 (6). 439-443.

[38] Anwar, K., \& Louis, R. (2017). Factors Affecting Students' Anxiety in Language Learning: A Study of Private Universities in Erbil, Kurdistan. International Journal of Social Sciences \& Educational Studies, 4(3), 160.

[39] Ali, B. J., \& Anwar, G. (2021). The Effect of Marketing Culture Aspects of Healthcare Care on Marketing Creativity. Ali, BJ, \& Anwar, G.(2021). The Effect of Marketing Culture Aspects of Healthcare Care on Marketing Creativity. International Journal of English Literature and Social Sciences, 6(2), 171-182.

[40] Ali, B. J., \& Anwar, G. (2021). An Empirical Study of Employees' Motivation and its Influence Job Satisfaction. Ali, BJ, \& Anwar, G.(2021). An Empirical Study of Employees' Motivation and its Influence Job Satisfaction. International Journal of Engineering, Business and Management, 5(2), 21-30.

[41] Khan, S. I., \& Abdullah, N. N. (2019). The impact of staff training and development on teachers' productivity. Economics, Management and Sustainability, 4(1), 37-45.

[42] Ali, B. J., \& Anwar, G. (2021). The balanced scorecard's evolution as a strategic mechanism at banking sectors. Ali, BJ, \& Anwar, G.(2021). The Balanced Scorecard'S Evolution as a Strategic Mechanism at Banking Sectors. International Journal of English Literature and Social Sciences, 6(1), 471-478.

[43] Anwar, G., \& Abdullah, N. N. (2021). The impact of Human resource management practice on Organizational performance. International journal of Engineering, Business and Management (IJEBM), 5.

[44] Abdullah, N. N., \& Anwar, G. (2021). An Empirical Analysis of Natural Gas as an Alternative Fuel for Internal Transportation. International Journal of English Literature and Social Sciences, 6(1).

[45] Ali, B. J., \& Anwar, G. (2021). Factors Influencing the Citizens' Acceptance of Electronic
Government. International journal of Engineering, Business and Management (IJEBM), 5.

[46] Anwar, G., \& Abdullah, N. N. (2021). Inspiring future entrepreneurs: The effect of experiential learning on the entrepreneurial intention at higher education. International Journal of English Literature and Social Sciences, 6.

[47] Prabhu, M., Abdullah, N.N., Ahmed, R.R. (2020). Segmenting the manufacturing industries and measuring the performance: using interval-valued triangular fuzzy TOPSIS method. Complex Intell. Syst.. https://doi.org/10.1007/s40747-020-00157-0

[48] Ali, B. J., \& Anwar, G. (2021). A study of knowledge management alignment with production management: A study of carpet manufacture in Kurdistan region of Iraq. Ali, BJ, \& Anwar, G.(2021). A Study of Knowledge Management Alignment with Production Management: a Study of Carpet Manufacture in Kurdistan Region of Iraq. International Journal of English Literature and Social Sciences, 6(2), 346-360.

[49] Ganeshkumar, C., Prabhu, M., \& Abdullah, N. N. (2019). Business Analytics and Supply Chain Performance: Partial Least Squares-Structural Equation Modeling (PLS-SEM) Approach. International Journal of Management and Business Research

[50] Ali, B. J., \& Anwar, G. (2021). Business strategy: The influence of Strategic Competitiveness on competitive advantage. International Journal of Electrical, Electronics and Computers, 6(2).

[51] Abdullah, N. N. \& Afshar, P. A. (2019). Investigating research and development costs on the profitability of Iranian industries. Journal of Organizational Behavior Research. Volume 4 (S2). 1-14

[52] Ali, B. J., \& Anwar, G. (2021). Marketing Strategy: Pricing strategies and its influence on consumer purchasing decision. Ali, BJ, \& Anwar, G.(2021). Marketing Strategy: Pricing strategies and its influence on consumer purchasing decision. International journal of Rural Development, Environment and Health Research, 5(2), 26-39.

[53] Abdullah, NN, \& Rahman, MFA (2015). Access to Government Information in Public Policy Making Process: A Case Study of Kurdistan. International Information Institute (Tokyo). Information, 18(8), 3447

[54] Ali, B. J., Saleh, P. F., Akoi, S., Abdulrahman, A. A., Muhamed, A. S., Noori, H. N., \& Anwar, G. (2021, May). Impact of Service Quality on the Customer Satisfaction: Case study at Online Meeting Platforms. In Ali, BJ, Saleh, Akoi, S., Abdulrahman, AA, Muhamed, AS, Noori, HN, Anwar, G.(2021). Impact of Service Quality on the Customer Satisfaction: Case study at Online Meeting Platforms. International journal of Engineering, Business and Management (Vol. 5, No. 2, pp. 65-77).

[55] Abdullah, N. N. (2018). Probing the Level of Satisfaction towards the Motivation Factors of Tourism in Kurdistan Region. 5(6), 439-443. DOI: 10.21276/sjebm.2018.5.6.3

[56] Ali, B. J., \& Anwar, G. (2021). Strategic leadership effectiveness and its influence on organizational effectiveness. International Journal of Electrical, Electronics and Computers, 6(2). 
[57] Saleh, P. F., Ali, B. J., Akoi, S., Najmalddin, B., Ali, R. S., \& Anwar, G. (2021). Factors affecting the Success of Female Entrepreneurs in Kurdistan. International journal of Engineering, Business and Management (IJEBM), 5.

[58] Othman, M., \& Abdullah, N. N. (2016). The Conceptual Assessment of Malaysian Entrepreneurship Environment and EO Economic Contribution. Journal of Resources Development and Management, 20, 15-20.

[59] Ali, B. J., \& Anwar, G. (2021). Intellectual capital: A modern model to measure the value creation in a business. Ali, BJ, \& Anwar, G.(2021). Intellectual capital: A modern model to measure the value creation in a business. International journal of Engineering, Business and Management, 5(2), 31-43.

[60] Abdullah, N. N., \& Othman, M. (2016). The Contribution of Human Capital Investment in the Growth of East Asian Economy-A Literature Review. Journal of Economic and Business Research, 22(1), 190-203.

[61] Ali, B. J., \& Anwar, G. (2021). Organization citizenship behaviour as a determining Factor in Business outcome. Ali, BJ, \& Anwar, G.(2021). Organization citizenship behaviour as a determining Factor in Business outcome. International journal of Rural Development, Environment and Health Research, 5(2), 17-25.

[62] Abdullah, N. N., \& Othman, M. B. (2021). Investigating the Limitations of Integrated Tasks on Youth Entrepreneurship in Kurdistan Region. Путеводитель предпринимателя, 14(2), 179-190.

[63] Abdullah, N. N., \& Abdul Rahman, M. (2015). Chinese Economic Activities and Interests in Developing Countries. Australian Journal of Basic and Applied Sciences, 9(25), 7986.

[64] Ali, B. J., \& Anwar, G. (2021). The mediation role of change management in employee development. Ali, BJ, \& Anwar, G.(2021). The Mediation Role of Change Management in Employee Development. International Journal of English Literature and Social Sciences, 6(2), 361-374.

[65] Top, C., \& Ali, B. J. (2021). Customer satisfaction in online meeting platforms: Impact of efficiency, fulfillment, system availability, and privacy. Amazonia Investiga, 10(38), 7081. https://doi.org/10.34069/AI/2021.38.02.7

[66] Demir, A., Maroof, L., Sabbah Khan, N.U. and Ali, B.J. (2020), "The role of E-service quality in shaping online meeting platforms: a case study from higher education sector", Journal of Applied Research in Higher Education. https://doi.org/10.1108/JARHE-08-2020-0253

[67] Ali, B, J. (2021). Impact of consumer animosity, boycott participation, boycott motivation, and product judgment on purchase readiness or aversion of Kurdish consumers in Iraq. Journal of Consumers Affaires; 1-20. https://doi.org/10.1111/joca. 12350

[68] Ali, B, J. (2020). Impact of COVID-19 on consumer buying behavior toward online shopping in Iraq. Economic studies journal. 18(42): 267-280. Retrieved from https://www.asjp.cerist.dz/en/article/134070

[69] Ali, B.J. (2021) Assessing (The impact) of advertisement on customer decision making: Evidence from an educational institution. Afak for sciences journal, 6(1): 425-439. Retrieved from https://www.asjp.cerist.dz/en/article/141056

[70] Ali, B.J. (2021) Consumer attitudes towards healthy and organic food in the Kurdistan region of Iraq. Management Science Letters. 11: 1-8. DOI: 10.5267/j.msl.2021.2.015

[71] Andavar, V., Ali, B.J., and Ali, S.A. (2020) Rainwater for Water Scarcity Management: An Experience of Woldia University (Ethiopia). Journal of Business, Economics and Environmental Studies, 10-(4): 29-34. DOI: 10.13106/jbees.2020.vol10.no4.29

[72] Faraj, K. M., Faeq, D. K., Abdulla, D. F., Ali, B. J., \& Sadq, Z. M. (2021). Total Quality Management And Hotel Employee Creative Performance: The Mediation Role Of Job Embeddedment. Journal of Contemporary Issues in Business and Government Vol, 27(1).

[73] Ali, B. J. (2016). Iraq Stock Market and its Role in the Economy. Retrieved from https://www.amazon.com/IraqStock-Market-Role-Economy/dp/3659634271

[74] Ali, B. J. (2014). Brand Building in the Consumer Electronics Industry in Iraq. Retrieved from https://www.amazon.com/Brand-Building-ConsumerElectronics-Industry/dp/6200248699

[75] Ali, B. J., \& Anwar, G. (2021). Capital Structure and Firm Profitability in Developing Countries. GOYA, 68(374), 163-174. Retrieved from https://goyajournal.org/index.php/goya/article/view/35

[76] Ali, B. J., \& Anwar, G. (2021). Factors Influencing the Citizens' Acceptance of Electronic Government. International Journal of Engineering, Business and Management, 5(1), 48-60. https://doi.org/10.22161/ijebm.5.1.5

[77] Ali, B. J., \& Anwar, G. (2021). The Effect of Marketing Culture Aspects of Healthcare Care on Marketing Creativity. International Journal of English Literature and Social Sciences, $\quad 6(2), \quad 171-182$. https://doi.org/10.22161/ijels.62.25

[78] Ali, B. J., \& Anwar, G. (2021). An Empirical Study of Employees' Motivation and its Influence Job Satisfaction. International Journal of Engineering, Business and Management, 5(2), 21-30. https://doi.org/10.22161/ijebm.5.2.3

[79] Ali, B. J., \& Anwar, G. (2021). The balanced scorecard's evolution as a strategic mechanism at banking sectors. International Journal of English Literature and Social Sciences, $\quad 6(1), \quad 471-478$. https://doi.org/10.22161/ijels.61.63

[80] Ali, B. J., \& Anwar, G. (2021). Self-Leadership Skills as Intangible Resources for Sustainable Competitive Advantage. Gongcheng Kexue Yu Jishu/Advanced Engineering Science, 46(1), 88-104. Retrieved from https://gongchengjournal.com/index.php/AES/article/view/10

[81] Ali, B. J., \& Anwar, G. (2021). Health sector reform: A Change Management Perspective on Health sector Reform. Gongcheng Kexue $\mathrm{Yu}$ Jishu/Advanced Engineering Science, 46(2), 29-38. Retrieved from https://gongchengjournal.com/index.php/AES/article/view/13 
[82] Ali, B. J., \& Anwar, G. (2021). Organizational Learning as A Determining Factor in Firm Performance. GOYA, 68(374), 193-202. Retrieved from https://goyajournal.org/index.php/goya/article/view/40 